\title{
Illustrations of the Structure and Life-history of Puccinia Graminis, the Fungus causing the 'Rust' of Wheat.
}

BY

H. MARSHALL WARD, M.A., F.L.S., F.R.S., Fellow of Christ's College, Cambridge, and Professor of Botany in the Forestry School, Royal Indian College, Cooper's Hill.

With Plates XI and XII.

$7 \mathrm{HE}$ accompanying figures, in illustration of the biology 1 of the Fungus which causes the Rust of Wheat, have been prepared in continuation of the series of illustrations of life-histories of parasitic fungi which I was commissioned to make for the Science and Art Department, South Kensington, and the first of which (on the fungus of the Potatodisease) appeared in the Quarterly Journal of Microscopical Science in $1887^{1}$. As before, the text is only to be regarded as a description of the figures in the plates, and $I$ have purposely avoided any reference to matters of theory, and also to several points of interest which have cropped up during the investigation.

Fig. I (Pl. XI) was drawn from a longitudinal section through a still green leaf of the wheat, attacked by the fungus in what is termed the Uredo-form. It shows the epidermis, to the left above, with a stoma in nearly median longitudinal section. Below this are several mesophyll-cells of the leaf, with their curiously sinuous outlines, and the large intercellular spaces between them; these cells contain chlorophyll-corpuscles. To the right below is part of a vascular bundle in oblique

${ }^{2}$ Q. J. M. S., vol. xxvii. part 3. p. $4^{\text {I 3. }}$

[Annals of Botany, Vol. II. No. VI, August 1888.] 
longitudinal section: it is already discoloured. Further details are not shown. In the intercellular spaces of the right-hand moiety of the figure are the fine septate branching hyphae of the fungus, and these are giving rise beneath the epidermis to the first series of spores, known as uredospores; all stages of development being shown, as the uredospores force up the epidermis, rupture it, and appear on the surface as the rusty streaks so hated by the farmer. (Zeiss B.)

In Fig. 2 are seen the details of development of the uredospores under a higher power. Separate branches of the septate mycelium (which contains protoplasm with scattered, oily, orange-red drops) ascend and become swollen at the tip: the tip becomes full of very dense, fine-grained protoplasm, and a septum is formed across below the swelling. The swelling enlarges, and its oil-like orange-coloured contents increase in amount: the cell-wall thickens also, and a pale central nucleus-like body is seen at a certain stage. Further enlargement follows, the orange contents increase in amount and in depth of colour, and the cell-wall becomes thicker: then regular spike-like projections are formed on the outside of the thickened cell-wall. When the spore is completely developed, as in the larger specimen above, the wall is found to be divisible into at least two evident layers, a thick outer exosporium, which is in its turn stratified into at least two layers, and a very thin endosporium. The spore is ellipsoidal in form, and has three or four rather large germ-pores at equal distances apart on a zone midway between the two ends: the germ-pores are really pits-thin circular depressions in the inner part of the endosporium and exosporium, and they serve for the emergence of the germ-tubes. Occasionally there is a thin place at the end where the spore is joined to the stalk. (Zeiss E.)

Fig. 3 shows a series of four successive stages in the germination of the same uredospore, sown in water on glass. In $a$ are seen two germ-tubes, emerging from opposite germpores; $b$, several hours later ; $c$, later still. It will be noticed 
that the granular protoplasm of the spore becomes vacuolated, and the contents pass into the germ-tube. (Zeiss E.)

Fig. 4. A longitudinal section through the leaf of a young wheat-plant, on which uredospores had been allowed to germinate for forty-eight hours. The section passed through a stoma, cutting one of the guard-cells (omitted in the drawing); through the cut guard-cell is seen the germ-tube from an uredospore which had germinated on the epidermis. The tube had formed a slight swelling over the stoma, and then entered; its end branches around one of the mesophyll-cells bounding the respiratory cavity. The nucleus of the distal guard-cell is very clearly seen. Orange-red granules are observed in the protoplasm of the germ-tube.

In Fig. 5 (Pl. XII) is a group of the teleutospores, obtained from a longitudinal section of the dry ripe straw of the wheat. The mycelium has now completely destroyed the cellular tissue, and its branches produce the two-celled elongated teleutospores, instead of the uredospores; specimens can be obtained with both uredospores and teleutospores arising from the same matrix. In this stage the fungus was named Puccinia. (Zeiss B.)

Fig. 6 shows in greater detail two of the teleutospores from the above patch. As before, each arises as a swelling at the end of a hypha; this club-shaped swelling becomes filled with dense protoplasm, and separated off from its pedicel by a septum. The young spore is then divided into two by a horizontal wall, and each of the two cells acquires a very thick hard coat, divided into several strata, as shown in the drawing. The colour also becomes much darker than before, the outer coats of the exosporium especially being siennabrown; owing to this the streaks of teleutospores on the wheatleaf appear brown or nearly black, in contradistinction to the orange-red streaks of uredospores. These teleutospores, developed in the autumn as the wheat ripens, contain oily drops in the protoplasm, and the outer shells of the exosporium are cuticularised. Unlike the thinner walled uredospores, which are developed in the summer (July) and germinate 
forthwith, these teleutospores need to be kept for some time before they will germinate. In the usual case they are scattered with the straw, and germinate in the following spring. (Zeiss E.)

Fig. 7. Four teleutospores germinating. The one to the left and that to the right had been kept for three years in my laboratory, and germinated as seen after lying for three days in water on glass. The two middle specimens, left uncoloured, were six months old. The process of germination consists in the erosion of the thick exosporium from within, the contents enveloped by the endosporium dissolving their way through at some one point; both cells may germinate, or one only. The germ-tube grows to a short and often curved (or longer and straighter) pro-mycelizm, which gradually acquires all the contents of the cell of the teleutospore, except perhaps a few granules and an oily drop or two. This pro-mycelium then becomes segmented into four or five (occasionally three) one-celled joints by transverse walls. Each cell of the promycelium then puts forth a short delicate branch, sterigma, much thinner than itself, and the tips of this sterigma slowly swells up into a spheroidal vesicle, sporidizm, which takes up all or nearly all the protoplasm; occasionally the sterigma branches and more than one sporidium is formed. These sporidia are very minute, as may be seen by comparing Figs. 5 and 7. All attempts to cultivate them on wheat have failed, and De Bary discovered the remarkable fact that they develop successfully only on the barberry.

Fig. 8. Three of the sporidia germinating in water on glass. (Zeiss E.)

Fig. 9. This preparation is taken from De Bary, and represents three of the sporidia germinating on the epidermis of the barberry-leaf, and sending their germ-tubes through the cuticle into the plant below. In the leaf of the barberry, the mycelium developed from these tubes ramifies between the parenchyma cells, as septate branched hyphæ, with orange-red granules in the protoplasm (see Fig. 10 $a$ ), and eventually produces the form known as Aecidium Berberidis. 
Fig. 10. Transverse section of a leaf of barberry infested with the Aecidium-form. The section has passed through three spermogonia and two aecidia (to the right below). The mycelium, ramifying in the mesophyll of the leaf, causes hypertrophy-due to the stimulated cells acting as centres of attraction for larger shares of food-materials, and then growing abnormally rapidly at their expense-whence the cushion-like thickening especially on the under side of the leaf. After developing in the cushion for about eighteen or twenty days, spermogonia begin to form, especially (but not only) on the upper surface. All that I can say about their earliest stages is that closely-woven balls of hyphae arc formed below the epidermis, gradually become larger and hollow, and burst at the apex through the epidermis. After developing several series of spermogonia, the mycelium begins to form larger balls of interwoven hyphae beneath the epidermis of the lower side of the leaf. These gradually increase in size, and form the aecidia-hollow, spheroidal cavities filled with the aecidiospores. By this time the cells of the mesophyll in the neighbourhood of the aecidia are becoming disorganised: the chlorophyll-grains lose their firmness of contour, and the walls of the cells turn light brown, as shown in the figure. (Zeiss B.)

Fig. $10 a$. Vertical section through an aecidium much more highly magnified. The aecidium is seen to consist of a cuplike casing of cells, peridium, with thickened and striated outer walls and orange contents, enclosing vertical series of aecidiospores developed in regular rows from the basidia below; as seen in the figure the peridium is simply formed by a modified series of cells with similar origin to the aecidiospores-all spring from a radiating series of basidia, which, again, are merely branches from the mycelium. At first the peridium forms a closed body (see Fig. 10 to the right below) beneath the epidermis; but as development proceeds the epidermis is ruptured-often at a stoma-and the peridium separates above. The aecidiospores ripen from above downwards, i. e. the older ones are ripe and separate off, 
222 Marshall Ward.-Structure of Puccinia Graminis.

before the lower ones of the same series. The successive development of spores continues for some time; the young crowded spores assume polygonal shapes, but they round off as they ripen and their walls thicken. I have repeatedly examined these aecidia in the youngest stages discernible, and can find no trace of sexual organs; the search for such organs has been equally unsuccessful in aecidia of other species-e.g. those on Ranunculus and on Tussilago. The basidia clearly arise from a tufted felt of mycelium, continuous with that in the tissues of the leaf, but no definite organs of the nature of sexual organs were discovered. The aecidiospores will germinate readily in water on the leaves of the wheat, and their germ-tubes enter the stomata, and develop a mycelium which gives rise to the uredospores and eventually to the teleutospores of Puccinia Graminis. (Zeiss E.)

Fig. I I. A portion of a very thin section thirough a spermogonium (Zeiss $\mathrm{E}$ ). To the right below a filament and its spermatium more highly magnified (Zeiss J). 

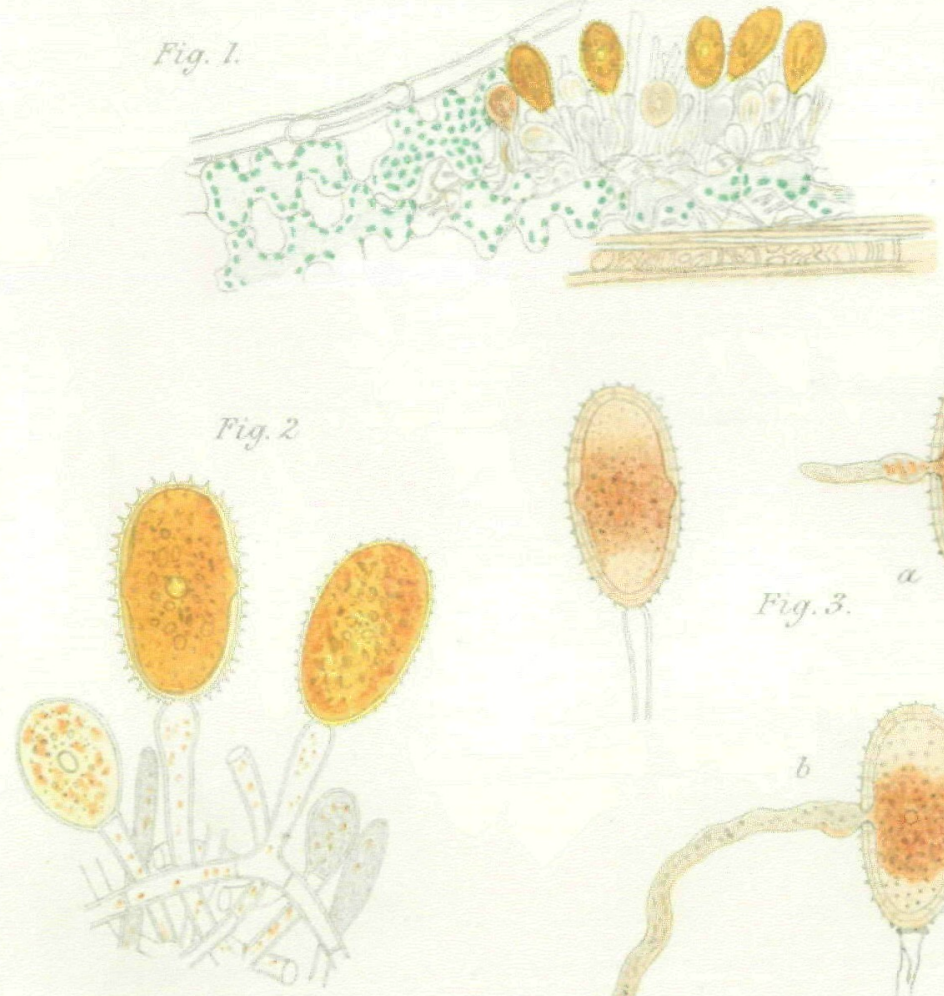

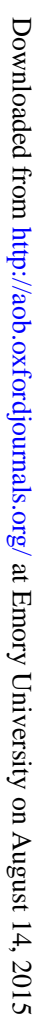

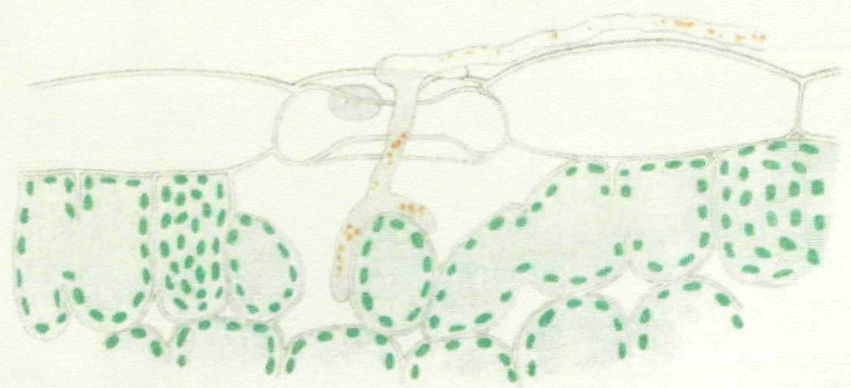




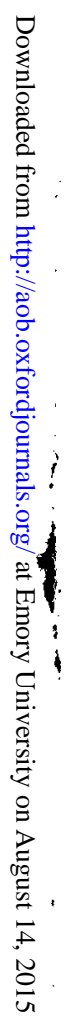

L 


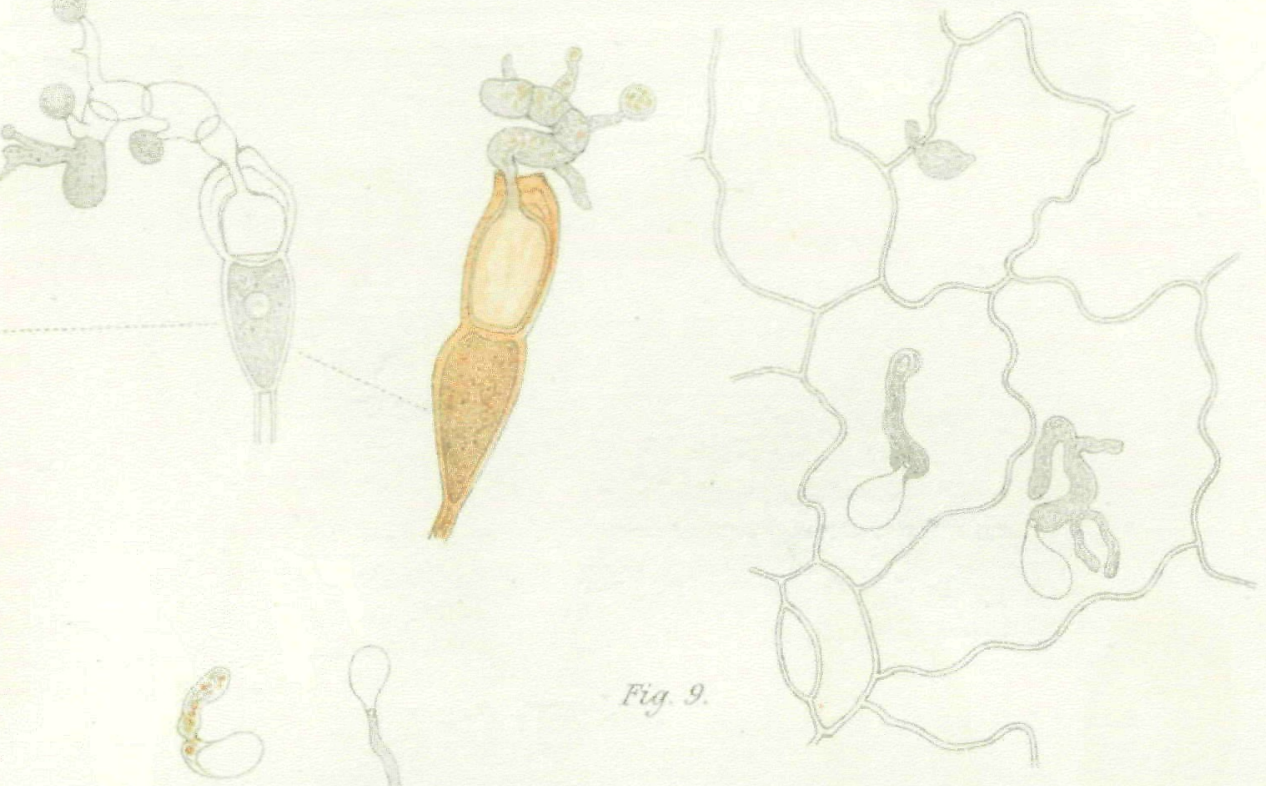

Fig. 8

nestrent

Fing 9

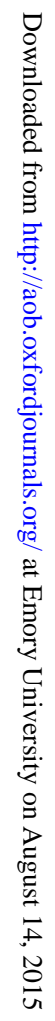

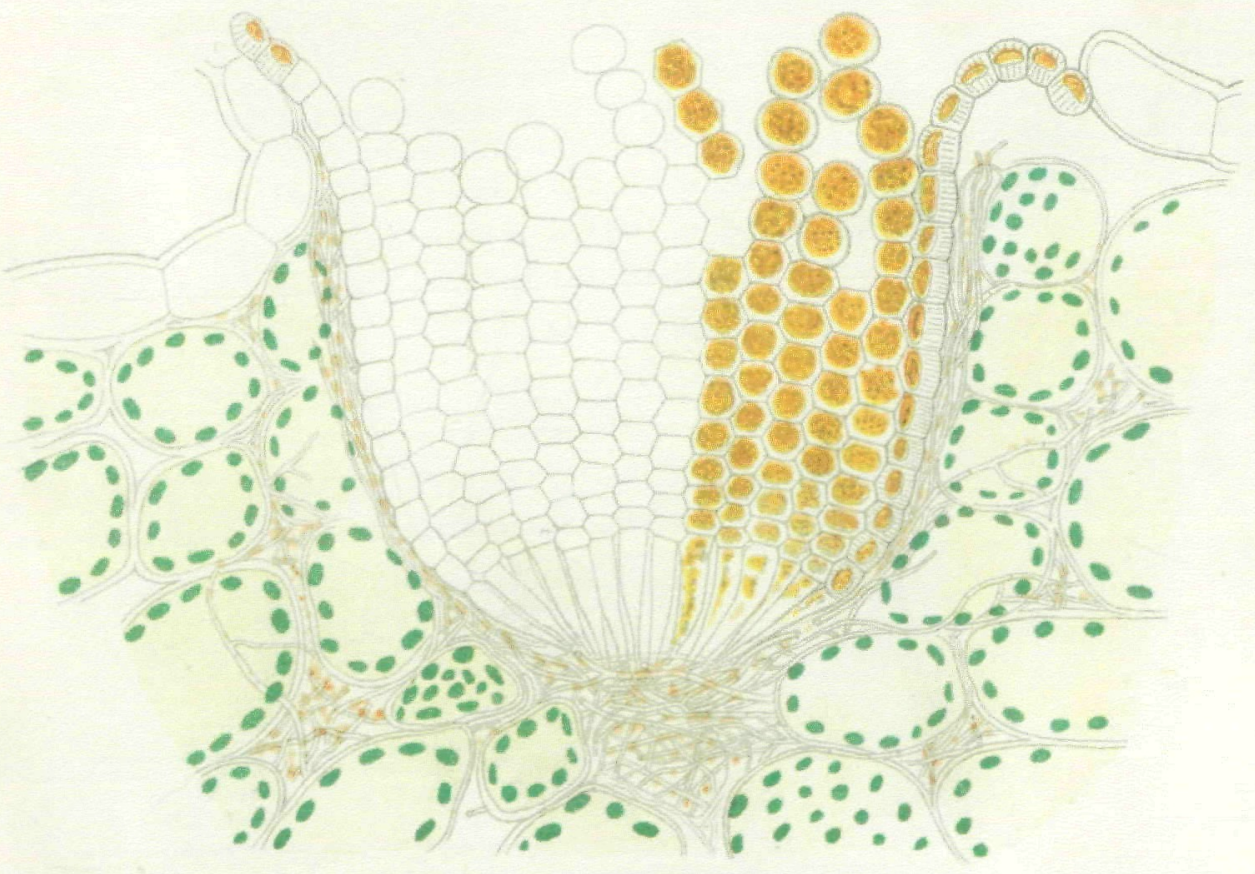

Fig: 70 a. 


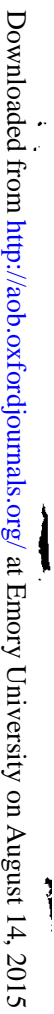

